o

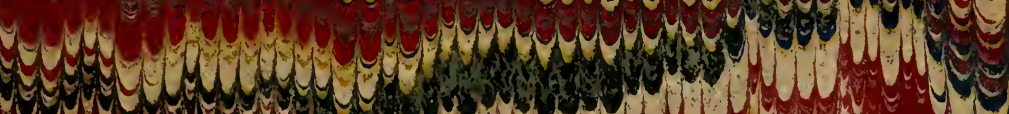
2. c.

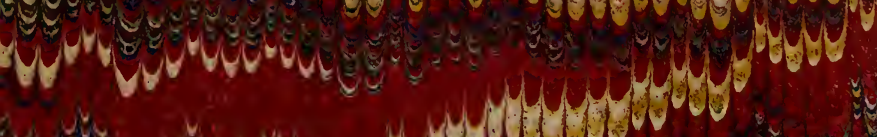

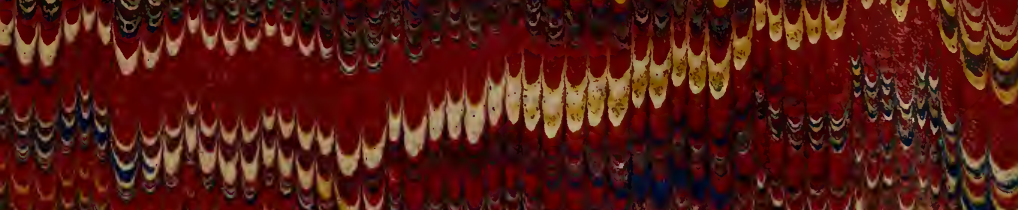

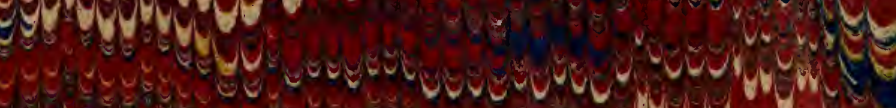
Who QH. T. W

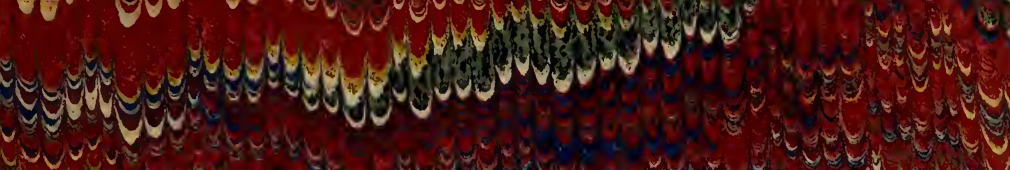

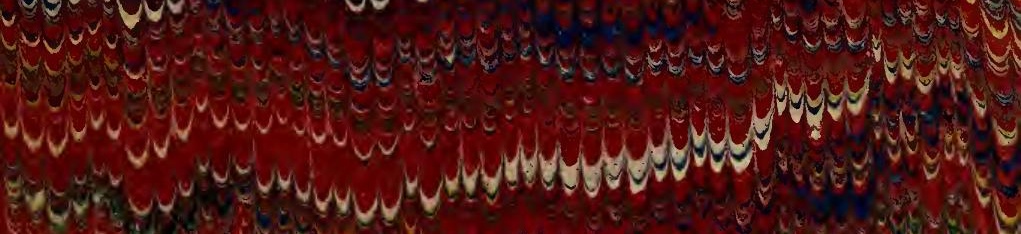

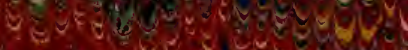
(1)

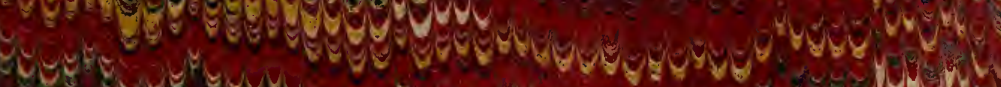

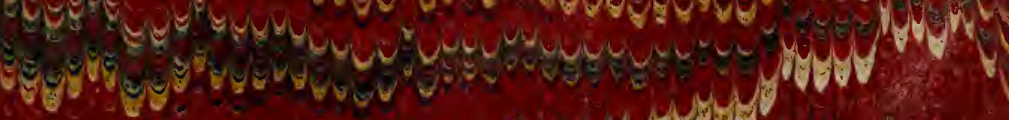

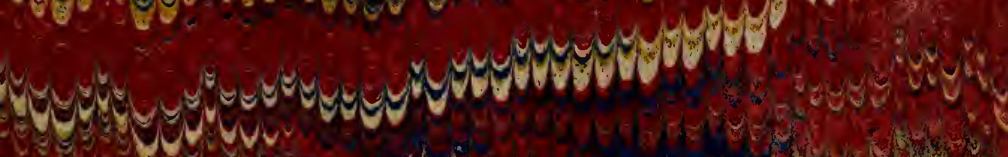









\section{WEALTH AND HEALTH.}

OR.

\section{A GUIDE TO PARENTS}

in таx

\section{EDUCATION OF CHILDREN.}

PREPARED FOR THE USE OF SCHOOLS AND FAMILIES.

\section{BY REV M. W. JACKSON,}

CHARLOTTE COUNTY, VA.

\section{R I C H M O ND :}

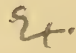

RITCHIES \& DUNNAVANT, PRINTERS. 


$$
\begin{gathered}
5 \times 9^{5} \\
316
\end{gathered}
$$




\section{ADDRESS TO PARENTS:}

INTRODUCTORY TO A WORK ENTITLED

\section{WEALTH AND HEALTH.}

IT is a strange fancy in the world of mind, that some of the most important subjects that can claim the attention of youth, and of mankind generally, should be entirely omitted in the course of a common school education. Although we usually devote a full share of time and attention to the languages and sciences, as liberal accomplishments, the mind is left a perfect blank in regard to agriculture, medicine, and some other subjects of daily necessity. The miserable policy of keeping children at school during nearly the whole period of their minority is now the fashion of the day; and if they learn nothing there of matters most vital to their welfare, except by accident, they must grow up to maturity, in total ignorance of the end of their creation, and become, to say the least, mere ciphers in society. 
Agiselaus, king of Sparta, when asked what things boys should learn, replied: "Those things which they will practice when they become men." Five or six years, with good teachers, are sufficient for the acquisition of a good English education; and this is all that can be expected for a large majority of children. But this should be thorough and complete, and the senior year should be delayed until the mind is so matured as to comprehend the higher branches. Many of our greatest men had to educate themselves almost without schools or colleges, funds or friends: and they became original and independent thinkers; they learned energy as well as science, practice as well as theory.

We are far from being opposed to a system of general education, nor would we repudiate the branches usually taught in our schools, especially philosophy and chemistry; but would say, in the language of holy writ, "These ought ye to have done and to leave the other undone." We think special attention should be given to the most important subjects; but it is not to be expected that half grown boys, by the study of a few good books, will make judicious farmers or skillful physicians. Our youth, at an early period, should have their minds directed to the ways and means of support, and the best methods of promoting health, as subjects of primary importance, and they will learn something 
valuable, that will leave its impress to the last day of life. In reference to the first of these subjects, we would adopt the language of Mr. Edmund Ruffin, the agricultural patriarch of the present generation: "Agriculture, as an employment of labor and the means of drawing subsistence from the earth, has generally been conducted with less knowledge and skill than any other ordinary business. The most ignorant of the human race may know that, by covering seeds in the soil and weeding the growing plants, crops of greater or less amount can be obtained; and it seems to be thence inferred that less instruction and less preliminary knowledge were required for the proper tillage of the earth, than for any other business or pursuit of man. But though scanty products and profits may be derived from the rudest processes, there is no employment of man, whether of science or art, which requires such varied knowledge, skill and judgment, as does agriculture; consequently, no pursuit more needs instruction for its young votaries. Yet it is almost the only business or profession which is without regular and ordinary instruction, and in which every learner is without a teacher."

While we would not disparage the interests of the mechanic arts and mercantile pursuits, we would ask, shall a calling which eight-tenths of the people pursue, and upon which all depend, 
the best of all others for wealth, health, innocence and virtue, continue to be regarded with such indifference and thrown in the back ground, while we give prominence to light and trivial matters? Shall Virginia, with as rich a soil as any on earth, and the most genial climate, suffer her sons to grow up in ignorance and idleness, and thus fall behind, in character and power, many of her sister states less favored by nature? With a territory thirty per cent. larger than New York, we have only one-third of her congressional representation, and yet, with a very little improvement in the science of husbandry and in habits of economy, we could support three times the amount of our present population. We have indeed a sad omen of the future in the almost unlimited indulgence that is in these prospcrous times, allowed the rising generation, particularly in those families who are in circurnstances of ease and affluence. If they will not regard the evils inflicted upon their neighbors by a bad example, and the voice of an enlightened conscience, they should at least consider their own interest and that of their posterity; for soon the wheel of fortune will carry them down to the vale of obscurity and misery, and those who are not ashamed to labor or too indolent to give an attentive eye to the movements of their operatives, will possess the wealth of the country, until they in their turn pursue a similar 
course. The wise man says, "drowsiness shall clothe a man with rags;" and poor Richard says, "not to oversee workmen is to leave them your purse open." Soon we must sell our negroes, and then our lands, abandon our country, and let the energetic Yankee monopolize the place of our nativity and convert the Old Dominion into a free state. But if we are not deaf to the calls of duty and dead to our interests, we will retrace our steps, and, to use the language of Mr. J. R. Edmunds, at the late fair, "in the development of her material power, fanaticism shall find an impassable barrier, and our peculiar institutions security." The only ray of light that falls upon the general gloom is the recent formation of the Virginia agricultural society, and we trust the zeal of twenty thousand citizens will not evaporate with the first exhibition. And let us not think our duty done when we get a premium for a pig or sheep, but let every man go to work and improve his farm, and teach practical lessons of industry and frugality to his children. Let us have auxiliary societies in every county, and public lectures for the people. Let us introduce this subject earnestly into our schools, and have books and papers adapted to our exigences. Mr. Tyler speaks in the language of hope when he says "The agricultural society of Virginia is now a fixed fact, and its benefits are des- 
tined to roll over our land in a mighty volume, causing the desert places to bloom and blossom like the rose, and our beloved state to raise its head proudly among the nations." The true response is energy, not enthusiasm, works not words. Inattention to business results not only in pinching penury and mental agony, but in shocking vices and degradation of character.

It has been well said, "the idle man's "head is the devil's workshop." Shall parents, with an undying instinct to love and cherish their offspring, rear them up for no purpose under the sun but to be a curse to God's creation? Shall every subordinate animal and insect be busy in fulfilling its destiny, and can man with impunity claim exemption from duty? "Go to the ant, thou sluggard; consider her ways and be wise; which having no guide, overseer or ruler, provideth her meat in the summer, and gathereth her food in the harvest." Prov. vi, 6-S. No father should be considered a good citizen, who, through remissness or recklessness, turns loose upon society, a family of dissolute and worthless children. He alone is invested by law both human and divine with power to guide and govern them, and he should be held responsible at the bar of public sentiment, as he certainly will be at the bar of God. They should be taught to rise early, redeem the time, stay at home, renounce their 
sports and attend to business; and they should be required to do it promptly and neatly. If we have colored laborers, it is no reason why any man should think himself too good to plough, dig, maul or haul when it comes in the way. "It is a sad misfortune," says Bishop Andrew, "for children to have servants to wait on them;" and my mother said she would rather indulge her servants than her children. Children by nature are full of life and animation, and will be busy in good or evil, and it is an easy matter to train them to business if you begin early. The boys will have their little wagons, horses, ploughs, \&c., and the little girls their dolls, beds and tables; but how few parents in this day of trade and travel, are studiously employed in monlding the mind, the heart and the character? How can they perform this all important duty, when a majority of them are ever on the wing, and know as little about their offspring as the ostritch of the desert? Will a father compass sea and land to amass a fortune for his neglected progeny, only to spur them on in a course of dissipation, until the last farthing is spent in riotous living? Thousands of dear mothers with the endurance of martyrs are wasting their strength to arrest the evil, but they are neither omnipotent nor omnipresent, and can have but little control over boys, unaided by their fathers. Farmers should keep their business snug, 
love their homes, and make companions of their wives and children. They have or may have the whole world in miniature about them, and are independent of the universe for sources of pleasure and of profit. But their calling is in so little repute, even in their own estimation, that when they seek employment for their children, they too often think the labors of the farm degrading, and if none of the learned professions are accessible, thrust them into groceries and taverns, where half their time they have nothing to do, and are ever exposed to the very worst influences. The farmer or planter may be as learned as any other man, and if he see cause, can give his children a liberal education; but there is great danger in sending half grown boys to distant schools and colleges. How can christian parents obey the command of God to "bring them up in the nurture and admonition of the Lord," when at this early period they are entirely removed from their supervision and control? As many of the best geniuses have been blighted by this mistaken policy, we would say they would do better to stay at home until their minds are matured and their characters formed ; for Solomon says, "Wherefore is there a price put into the hand of a fool to get wisdom, seeing he hath no heart to it." Teachers now often find it impossible to control scholars, but these gay and giddy gentry, so commonly adorned 
with rum blossoms and perfumed with cigars, might have made wise men and useful citizens, had they been kept at the plough, the bench or the anvil.

And the daughters of the land should be taught to frown upon dandies and rowdies, and seek companions among steady, industrious men. The great Washington said, "Agriculture is the most healthy, the most useful, and the most noble employment of man." And the disease which ended his brilliant career, was contracted by exposure in attending to the business of his farm. I rejoice that we have yet in Virginia a remnant of the good old Roman stock who are not ashamed to work, but think it a shame for any man or woman to be brought up in idleness. They find it difficult to stem the mighty current that bears against them, but soon we trust the tide will be in their favor. Certainly, if reason and revelation, conscience and common sense are regarded, we shall speedily have a reformation. The old proverb is, "He that raises his son without a trade, teaches him to steal." And the verdict of revelation is, "If any will not work, neither shall he eat." In view of this state of things at the present crisis, the first part of our work is made to consist of a short treatise on agriculture, principally in its practical details as hints to farmers in general, and to youth somewhat advanced in their education. And in connection, as a part of the course, we 
would recommend Norton's Elements of Scientific Agriculture.

Next to food and raiment, in importance for comfort and usefulness, is the health of our bodies; and every son and daughter of Adam's race should be taught something of the healing art in connection with anatomy and physiology. But we may be told, "a little learning is a dangerous thing." And perhaps the poet practiced on this sentiment, when he fell a martyr to his appetite, from a surfeit on anchovy sauce. Shall a man know nothing of diseases or remedies, of poisons or antidotes, because he has not a diploma? Or shall we adopt the maxim of the Jesuits, that " ignorance is the mother of devotion?"- "Haif the time and attention which are devoted to the minor politics, arising out of our party dissensions," says an eminent medical writer, " would, if appropriated to medical studies, enable any person of tolerable capacity to practice with safety and advantage in those cases of simple disease which are most incident to our climate, and to determine between the arrant quack and the modest, well educated and judicious physician." The human body is a most wonderful and perfect piece of mechanism, formed by the wise and benevolent Creator to operate in health and harmony, (without some special adverse providence,) for three score years and ten; but by the ignorance 
and recklessness of mortals, long in advance of that time, its functions are deranged and its energies broken down. It cannot be pleaded in truth, that this happens mainly to invalids from some hereditary infirmity; for generally the most robust and vigorous, in consequence of some indulgence or rashness, are cut down first, and thus many valuable lives are lost. Bacon said, "The only cause of death, which is natural to man, is old age." As a general rule, we should not consider our pains and diseases as unavoidable accidents, but as fruits of our folly.

I think the Spectator says, "When I see a table loaded with rich meats and custards, accompanied with sauce and wines to stimulate the jaded appetite, I fancy I see concealed under the dishes, gouts, rheumatism, jaundice and a long train of painful disorders, ready to fasten upon the merry company." And Dr. Franklin says, "Since the art of cookery has been so much improved, mankind generally eat about twice as much as nature requires." But how few have the first thought that a majority of our diseases and deaths originate from these excesses? Many disbelieve it altogether, and others will tell you that the remedy is worse than the disease. We have seen some of our best friends fall in this way, and others have been saved by giving ear to a little advice. The habits of children 
in this respect should be noticed, and they should be taught lessons of prudence and self denial. The evil is not limited to physical debility and premature dissolution. The noble mind being dependent on the condition of the nervous system for the exercise and development of its powers, is generally enfeebled in the same proportion, and there is an incalculable waste of talent that might be employed for the good of the community. Indeed, we suppose there is no such phenomenon in nature as mental derangement or imbecility, but conclude that all apparent feebleness or aberration, whether in infancy, maturity or old age, is the result of physical infirmity. Not only do we see that the prevalent and disgusting malady denominated mania potu is the result of strong drink, but fits in children, and folly and insanity in adults, might often be prevented by a little restraint upon their diet. And is it unreasonable to suppose that Franklin was indebted to his vegetable diet for his remarkable vigor of mind and energy of character? A new and cheap edition of his life and essays at this crisis might make a favorable impression upon the minds of our young men. It is a work that should be in every family, but I think there are not many copies now in the country. We have so little knowledge of pestilential gasses, have so little prudence in our indulgences, and are so often exposed to danger 
even in the discharge of duty, that sooner or later diseases will come; and it is highly important that all heads of families at least should be acquainted with the most efficient and common remedies, and with the symptoms of prevalent diseases. A man who knows the constitution and habits of his wife, child or servant, if he is a man of experience and prudence, can sometimes practice with as much safety as the most skillful physician, and a dose of medicine at the proper time may save life; but a partial acquaintance with the subject will not do away the necessity of medical advice in different cases. Let no one be frightened by a few hard words to think it a kind of free masonry locked up in mystery from all except the initiated. The names of things as in law are generally in Latin or Greek, but the things themselves are plain and simple. For instance, sal commune in Latin signifies common salt, and cutis vera, the true skin; but these mysteries are sometimes convenient upon the score of modesty. We see no necessity for such profound mystery upon a subject that all ought to understand to a considerable extent; and if the pupils cannot study the dead languages, they can learn the definition of the words in a dictionary or glossary. "It is somewhat unaccountable," says Dr. Dick, "and not a little inconsistent, that while we direct the young to look abroad over the sur- 
face of the earth, and survey its mountains, rivers, seas and continents, and guide their views to the regions of the firmament, where they may contemplate the moons of Jupiter, the rings of Saturn, and thousands of luminaries placed at immeasurable distances, we should never teach them to look within themselves; to consider their own corporeal structures, the numerous parts of which they are composed, the admirable functions they perform, the wisdom and goodness displayed in their mechanism, and the lessons of practical instruction which may be derived from such contemplation."

On this branch of medical science we would here recommend "Cutler's Anatomy and Physiology, designed for Academies and Schools," a small volume with over two hundred engravings; but as we have seen nothing on pathology and the practice of medicine adapted to schools, we have, by the aid of some medical friends, prepared a condensed treatise upon those branches, which constitutes the second part of our volume. 'The Thompsonian system may have its merits, when in the hands of judicious men, but from some experience and observation, we have been induced to consider calomel the Sampson of the materia medica, especially in the diseases of white people, in which the liver is apt to be more or less implicated. And children can be induced to take it 
without being aware of it, when it is very difficult to get them to drink large draughts of lobelia, pepper, \&c. Upon this subject we will only add, that we have had a family for more than a quarter of a century, and under the old practice, by the blessing of a kind Providence, we have yet to witness the first death in our household.

Another subject which we think is sadly neglected in our schools is religion, and the proper text book is the Bible, which is now almost discarded. This indicates a bad moral condition, both of teachers and patrons. Will a wise people endeaver to blot out the sun, that they may be guided by a feeble taper? Yet in substance this is recommended and to a considerable extent adopted as one of the improvements of the age. If its style is a little antiquated, as is sometimes argued even by members of the church, there is an ample atonement made in the sublimity of its doctrines and the purity of its precepts; and its power is far superior to that of the birch in securing subordination. If it cannot be systematically taught and expounded, at least let it be read with seriousness, and portions of it committed to memory. This is the more necessary, as there is reason to fear that since the vast multiplication of books and papers, it is more neglected in families than formerly. Not only every christian, but every patriot and philan- 
thropist should be firmly fixed upon this point. And the Sabbath school, that efficient substitute for the labors of delinquent parents and teachers, should be encouraged and sustained as far as practicable. Our president, following in the footsteps of the illustrious Washington, in his tone of moral feeling, says, "It is my deepest conviction that we can place no secure reliance upon any apparent progress, if it be not sustained by national integrity, resting upon the great truths affirmed and illustrated by divine revelation." The term cducation is greatly misapplied when made to signify merely a literary course of study. Literature alone has no sanctifying effect on the heart; and not unfrequently, as Paul says, "knowledge puffeth up," as we see in young men who despise their parents, who by their hard earnings have given them greater advantages for mental culture than they themselves possessed. The moral nature must be cultivated as well as the intellectual, or there is great danger that man in his depravity will be a demon in principle, whether shining in literary circles or unknown in the shades of retirement. Dr. Thornwell truly says, "Science languishes, letters pine, refinement is lost wherever and whenever the genius of religion is excluded." Religion, then, should be regarded as the first and foremost subject in any system of education, but I do not think it 
necessary to embody its doctrines and precepts in a text book, as we have one dictated by infinite wisdom, and acceptable to all denominations.

To aid parents and guardians in developing and directing the physical, intellectual and moral powers of the dear youth committed to their charge, I have found it necessary to prepare a book upon two neglected subjects which I deem of great importance; but we have already at least a sufficient number and variety upon other subjects. As we are decidedly opposed to the great variety of school books that has flooded the land of late years to the perplexity of teachers and the confusion of classes, we regret the necessity of making an addition to the number; but we will make a suggestion that may in some degree diminish this needless expense for the time to come. With the exception of Dr. McGuffey's series, we very much doubt whether there has been any important improvement in common school books for the last half century, and yet almost every new teacher must have a new set of books. It is not easy to find anything superior to Webster's Spelling Book, Pike's Arithmetic, and Murray's English Grammar. Both for our purse and progress we would suggest to the friends of education in the state to call a convention of teachers and literary characters every ten years to examine school books, and recommend the most 
simple and lucid for the use of our primary schools, and let them promptly reject all innovations and alterations, unless when some important discovery is made.

M. W. J. 


\section{PART I. \\ A GRICULTURE.}

Columbia's sors, spurn not the rugged toil, The glory of your country is a cultured soil; Mount Vernon's patriot, of unrivaled worth, Increased his laurels while he tilled the earth.

"The aversion of farmers to consult books on agriculture," says Skinner, "doubtless arises in a great measure from the neglect of parents to have agriculture, and studies nearly akin to it, made a part of the education of their sons." Books written by experienced practical inen do not consist of ingenious speculations and abstract theories, but mostly of well established facts, which may be of great value to the young, and to many adults ; and in a few hours, or days at most, these facts may be learned, which it would require years to know by incidental conversation and observation; and in the mean time many losses will be sustained by the repeated errors which we commit. Certainly an important truth loses none of its value by being in 
print; and a single hint may be worth more than the price of the book. For instance, two years ago I published in the Southern Planter a simple plan for keeping sweet potatoes, which has never been known to fail, and which I have given in this little book; and my father, for want of the knowledge, lost more every year in his potatoes than would pay for a large volume. The word agriculture is derived from two Latin words, ager a field, and colo to cultivate, and signifies the art or science of cultivating the earth to procure subsistence for man and beast. Its practical operations may be considered an art, and to use the language of Liebig, "A knowledge of all the conditions of the life of vegetables, the origin of their elements and the sources of their nourishment, forms its scientific basis." It is an avocation that should be well understood and held in high repute, as all classes of men are supported by it, and a large majority are necessarily engaged in it. The eloquent Major Wright of Missouri, at the fair of that state held at Booneville in October, said, "The highest attainments of science are yet to be won from the soil she has neglected, and the highest duty of the state is to place agricultural education within the reach of all her sons. Science, weary of the laggard and fickle motion of the winds, has seized the invincible strength of water, put it into iron harness, and now defies both wind and wave. 
By the united power of the locomotive and steamship, oceans dry up, continents shake hands, and Ariel's girdle belts the earth. But as yet agriculture is the only art left behind in this unparalleled advance of other arts and sciences." The subject embraces the consideration of soils and manures; crops and modes of cultivation; agricultural implements and machinery; draining and irrigation; fuel and fencing; stock raising and fattening.

\section{SECTION I.}

OF soILs.

There is a great variety of soils, and they should be carefully studied, not only that we may be able to make judicious purchases, but apply to each suitable manures, and put into them suitable crops. Norton says, "we can tell what is necessary to fertilize the most hopeless desert, but at the same time may not be able to conduct the operation so as to make it profitable. It becomes no longer a question of knowledge-it is one of experse." All soils have both a mechanical and chemical character, the first relating merely to the position of their particles as forming hard or soft land, the second to the composition and quality of their materials as rich or 
poor. When the farmer drains, ploughs and hoes his land, he alters chiefly its mechanical or physical character; when he manures it, he alters its constitution or chemical character. Each soil produces vegetation suitable to its own nature, viz: those plants which require for their growth those substances which actually abound in it, as we see in the production of sorrel on acid soils, and the failure of tobacco or wheat on rich lots after several successive crops, thus requiring a rotation of crops. But the evil might be remedied by supplying the deficient material. Some soils are red and stiff, and are best adapted to wheat and clover; others are light and sandy, and are more suitable for corn and oats, and when the sand is of a fine texture, they suit tobacco. They imbibe too much water for wheat, and if it is put into them they require rolling or treading. But to be more particular, soils may be distinguished as silicious, aluminous and calcarious, according as silica, alumina or lime prevails. Leibig says, "Lime especially serves for resolving the silicates of alumina (clay,) and consequently it cannot fertilize soils in which clay is wanting, for instance, sandy soils."

An alluvial soil is a deposit in bottoms by the washings from the ; and mountains, and when not too sandy, is generally very rich. But the most of this, as well as the dark surface soil in our origi- 
nal forests, is a vegetable mould called humus. Some writers and most of farmers call it the soil, as distinguished from the clay or subsoil; and as Webster admits this definition in his Dictionary, we will adopt it. Loam may be considered a kind of artificial soil, made up of a mixture of others by the process of cultivation. The subsoil is divided into two classes: the first consisting of pure or pipe clay, but only found in small quantities; the second, of unctuous or tile clay, including in it a portion of sand. But the clay is formed of more simple materials, as alumina, silica, magnesia \&c. The crust of the earth, it is thought, has been mostly formed by the disintegration or crumbling of the great rocks that are found under its surface, inasmuch as there is generally a similarity in texture and character. Good uplands generally rest on limestone, sandstone, slate or granite; and these rocks contain silica, lime, potash, soda and other mineral manures. Forest land, not originally good, should, if practicable, be kept for timber and leaves or pasture, as it will not retain manure when applied, and is, therefore, called a leechy or hungry soil; and as proof we would say, it has had a heavy coating of leaves from the days of the deluge, and yeil has made no improvement. Such land, if made rich, is ever tending to its original poverty, and gond land, if made 
poor, to its original fertility. Lands composed of coarse sand or gravel, are necessarily poor from their mechanical structure, as most of the fertilizing matter, as soon as it gets into a fluid state, filtrates through them down into the bowels of the earth, beyond the reach of the growing crops; and as evidence, we have known springs and wells impregnated and injured by decayed matter from icehouses and grave-yards. This frail tendency in certain soils has been denied by some, and $\mathrm{Mr}$. Ruffin had doubts in regard to it; but in the last edition of his Essay on Calcarious Manures he admits that fertilizing ingredients may thus be lost by "penetrating to the sources of springs, either temporary or permanent, and pass into the streams." This idea is of great importance to the farmer, to prevent him from heedlessly wasting his manures. As soils are so various in Virginia, and often even on a single farm, and the opinions of learned men so discordant in regard to the causes of sterility, we do not know what to expect from chemical analyses of soils; but certainly the importance of the subject demands a full and fair experiment, and the growing interest in the public mind would justify the legislature in appointing a state chemist, if a suitable man could be found. But, at present, we think the best mode of knowing lands of good original quality is, to see their production or learn the 
history of their products. As a general rule we may suppose that our best lands were cleared first, and the tall pines, together with the turf that lines the galls and gullies, are good indications of power in the soil. While a leechy soil is ever crying "give, give, and is never satisfied," a lot of good land is like a horse of good constitution, easy to keep; and such lots may be found on most farms, particularly on the slopes near the streams. This may result from the rock underneath, which is generally nearer the surface than on table lands, or from the gases that arise from the streams and marshes.

\section{SECTION II.}

\section{MINERAL MANURES.}

The renovation of our exhausted fields is the point of greatest interest to farmers in the old states, where our best lands have been carried off by drenching rains or rendered lifeless by a long continued process of depletion. Our fathers, having an interminable wilderness before them, cared but little and knew but little about ameliorating the soil ; but their descendants are now pent up by the western ocean, and emigration has come to a dead halt. In 1620, the men of Plymouth rock saw the first light 
of morning gild the waves of the Atlantic, and now their descendants and our brethren see twilight deepen on the smooth waters of the Pacific. Our religion as well as our patriotism should rebuke our prodigality, and prompt us to study and practice habits of simplicity in our style of living, economy in our financial and fertilizing resources, and diligence in every department of business. Without a radical and speedy reformation, desolation and destruction will overtake us; but by giving heed to the mandates of reason we may become a prosperous and happy people, and bequeath the legacy to generations yet unborn. One important art for the improvement of our farms, is so to plough and trench as to retain upon our premises the little fertility we have left. It is surprising and sickening to the feelings to see the neglect in this matter in many sections of our country; and some who undertake it, work in such a way as to defeat their object. The farmer should never suffer a gully or gall to disfigure his fields, and the most of them can be healed up in a few hours with a little pine brush.

It has been often observed, that the site of an old dwelling house or granary, when put in cultivation after all the materials are removed, will retain its fertility for ages. The man who could account for this might with propriety receive a gold me- 
dal; but perhaps the benevolent Creator may choose to withhold this knowledge from us to find us employment and keep us out of mischief. I have two such spots on my own land, and have manured freely around one of them, and my application, although fully equal in efficiency at the time, has disappeared by successive crops, while that remains and will remain for generations to come. Some have thought that this remarkable retentiveness was produced by ashes in converting it into an alkaline soil ; but it occurs without ashes, and sometimes fails where ashes abound, as in case of a burnt tobacco barn. My own conjecture is, that it results from the length of time that was allowed the soluble ingredients in large quantities to sink into the subsoil, and the great depth to which they descencled, and thus they are retained and returned annually in small quantities; for this peculiarity is more visible on fine, compact soils. Shell marl, in lower Virginia, has performed wonders in renovating the soils, through the skill and energy of $\mathrm{Mr}$. Ruffin ; but as it is found only in the tide water districts, it can never be brought into general use. But if our soils are poisoned with the same acid as is found there, possibly the common carbonate of lime, which is now only 10 cents per bushel in the cities, might be a valuable antidote. The few experiments that have been made are rather contra- 
dictory ; but as we now have facilities for transportation, we could make the trial on small lots and in different modes. As to gypsum, (sulphate of lime,) Norton says, and we know it by experience, " there are many large districts where it produces no effect; but it may always be considered that where lime or gypsum do no good, there is already, in one form or another, a supply of both naturally in the soil, or some physical or chemical defect which prevents their action." On our light, sandy lands our fathers tried it many years ago, and laid it aside; but on red, stiff lands some still use it. From observing the luxuriant vegetation on the loose earth carried out from some of the deep cuts on our railroads, particularly where there was an appearance of felspar rock or slate, and the production from clay taken from cellars and ice-houses, I have thought it probable that we who are in the upper country might find valuable materials on our own farms equivalent to the clay marl of England. I have made some experiment with a soapy clay taken from a cellar, and it produced a heavy yield the first year, but it does not appear to be permanent. Perhaps we may find tufa among our rocks, and ultimately use the most of them, by burning or grinding as fertilizers. 


\section{SECTION III.}

PUTRESCENT MANURES AND GREEN CROPS.

So far as we can yet see, our citizens above tide water must depend for heavy crops chiefly upon vegetable and animal substances in a state of decay, and these are found to be rich food for all plants. If by our quackery in mineral medicines we are as liable to kill as cure, let us feed mother earth with nourishing diet in imitation of her own mode of regaining strength. If our nostrums do not quite extinguish the vital spark, they often afford only a temporary stimulus, which leaves her more prostrate than before. There is not only a remarkable similarity in the physiology of vegetable and animal life, but a great degree of identity in the elements that constitute the bodies of both classes of beings. "These three nitrogenized compounds, vegetable fibrine, albumen and caseine," says Liebig, "are the three nitrogenized constituents of the food of graminivorous animals, and they are identical in composition with the chief constituents of blood." Again he says: "The animal organism is a high kind of vegetable, the development of which begins with those substances with the production of which the life of an ordinary 
vegetable ends." If this analogy be true, is it analogous that vegetables should receive a portion of their food through their leaves, which are considered the lungs of the plants? I know a doubt upon this subject will be considered a heresy in science; but I have seen facts calculated to induce a belief that the whole of the pabulum, either in a gaseous or fluid state, enters through the roots. I saw, last year, a small field of corn, entirely surrounded with woods; and although a high land field, was equal in luxuriance to river bottom; and what was more remarkable, my attention being directed by the owner to the effects of a ditch cut on one side to sever the roots of the forest trees, I discovered the corn was equally good up to the fence, and old cultivators have long acted from this impression. But we admit, as in the animal economy, that the lungs (leaves) inhale gases to purify the blnod (the sap) and promote digestion and assimilation; and consequently that the atmosphere is as indispensable to plants as to animals. Professor Mapes, while he does not fully coincide with our fancy, says: "The carbonic acid of the atmosphere enters the roots of plants in solution with water, and in passing up through them deposits its carbon, forming the chief part of the dry weight of the plants, giving off its oxygen to the atmosphere." Professor Shulze says: "Carbonic 
acid is sucked in by the roots only, together with other nutritious substances." I make this digression to prevent farmers from destroying their timber to save their crops, as is sometimes recommended. If, in Flanders, the urine from a single cow is considered worth ten dollars per annum, and if the excrements from each animal and human being, if carefully preserved, will make at least as much as they consume, while nature is annually at work adding to our stores, what mysterious problem is there connected with the renovation of our sterile fields? But instead of covering these valuable materials in the earth, or with earth, we suffer them to waste by fermentation and evaporation, or run off into the streams; for when we smell the manure bank, or even a barn of tobacco, we may know a loss is sustained. Boussingault says, that "Dry stable manure, after heating in a thick stratum, has been known to lose nine-tenths of its weight, and of the remainder there was only one-third of its nitrogen left, which is the element that constitutes the nitrogenous principle of plants and the flesh and muscle of animals." The process of putrefaction, like that of digestion in the stomach, is a slow combustion, tending to convert all organized matter into its original elements, as fire acts on wood, and we should by no means allow it to take place in our manures until the crops have need of 
them. Major Wright of Missouri eloquently remarks, that "nitrogen has wings so nimble that they need clipping, and science only can perform that operation well. It presents an anomaly in nature. In the air it is in the midst of very active and combustible agents, that have a wide range of affinities prompting them to unite with many substances; but it is characterized by its utter indifference to all other substances-it has an apparent reluctance to enter into combination with any of them." Coarse litter, like stalks or straw, when kept covered by fresh accumulations, should lie long enough to undergo a partial decomposition, that they may be easily broken to pieces and handled, and refined for the convenience of ploughing them in; and a yard for feeding and treading should be formed, with a dish towards the centre, that the liquids may be saved. It is best when it can be done, to have the fields to corner near the dwelling, and have a permanent farm pen convenient to them all, that the farmer may have his stock and work more under his eye. All fine manure should be sheltered to preserve its strength and keep it light and loose for hauling and spreading. A Dutchman's barn is the largest and finest house on his premises, but a Tuckahoe will spend thousands for a fine dwelling, and leave sheds, shelters and cabins neglected. Much valuable manure 
might be collected from hogs, sheep and fowls, and that from fowls is richer than that from any animal, for the reason that we have the liquid and solid excrements mixed together. Hogs intended for pork should be kept up in close pens on plank floors almost from pigs, and fed like shoats on slops, vegetables, meal, corn, \&c., and the manure it is thought will amount in value to at least half the expense of fattening, and the meat will be better. It is almost needless to say, that we may find rich materials about our hedges, fences, houses, \&c., to say nothing of our marshes and streams. I shall say nothing of guano, as it is so well understood, and it is a little doubtful whether it will remunerate at present prices, if we should have bad seasons and depressed prices for produce. Green crops consist of clover and other grasses, cultivated to be turned into the soil as manure, and they are well worthy of attention if the farmer can find the time in the midst of his other engagements. Sir $\mathrm{H}$. Davy says: "When green crops are to be employed for enriching the soil, they should be ploughed in if possible when in bloom; for it is at this period that they contain the largest quantity of easily soluble substances, and that their leaves are most active in forming nutritive matter." But the fallow of clover should be delayed until the seeds ripen, to avoid the expense of buying seed, as they 
will remain in the earth, and stock his field for years to come. On light gray land not adapted to clover, he may substitute oats, peas or herds-grass, and before ploughing let his stock feed upon them; but for this kind of land I think hard treading and grazing is better than ploughing.

\section{SECTION IV.}

CORN.

"Ho that by the plough would thrive, Himself must either hold or drive."

Almost any land is good, and any crop profitable to the industrious, skillful and economical man, but without regular toil and unremitting vigilance his expenses will exceed his income, especially if much sickness occurs or several unfavorable seasons come in succession. If Infinite Wisdom saw it proper to put Adam in the garden "to dress it and keep it" while he enjoyed its fruits, how much more necessary is employment for his degenerate sons and daughters! The principal crops in Virginia consist of corn, wheat, oats, hay, potatoes, turnips, peas, pumpkins and tobacco; and we would say that by analysis it has been ascertained they are all composed mostly of four simple substances, carbon, oxygen, hydrogen and nitrogen, which are called 
organic substances because they are the products of vegetable life and forms the organs of the plant. In combustion these fly off into the atmosphere in the form of gas and vapor, and a few ashes remain, amounting only to eight or ten pounds in every hundred, consisting of potash, soda, lime, magnesia, silica, \&c., which are called inorganic substances. The quantity of these several elements varies in different plants and in different parts of the same plant, as in the grain and stalk; and animals prefer short grass because it is richest near the ground. Corn is the great crop in the South for thrift and comfort, as it embraces both bread and meat, and it should not be neglected or slighted for any other crop. Norton says "it is unrivalled in its quality for fattening, as it contains by analysis about ten per cent. of fatty matter." In selecting seed corn we should have regard to a long deep grain and small cob, as it yields more and is not so liable to rot in wet weather. Corn on the high lands should be planted early in April, but the flats will do well any time in May. All the flats intended for corn should be ploughed up in November or December by flushing in beds twenty or thirty feet wide, and the water furrows should be opened nicely with the hoe. If this is not done before the spring the wet portions will be sobbed to death, and thus the best land after much hard work will yield nothing. 
High land will do fully as well ploughed in the spring, and should generally be thrown up in single beds, that the land may not wash or bake, and the corn being a little elevated will take an early start; but the opening furrows for the reception of the corn should be very deep, and the corn planted low in the earth. In the culture the small dagon is generally used first in throwing the earth from the corn, and then in laying by the earth is thrown back, so there is but little necessity for the hoe. This is perhaps the best and cheapest method, but others prefer to have their rows on a level with the earth, and cultivate it with harrows and coulters. Deep ploughing is required in the whole process of cultivation, not only to render the land soft and friable for the progress of the roots, but to admit the gases and water freely, and prevent the land from washing. In long dry spells, to which we are so subject in the South, the corn will retain its color and vigor, and make a good yield with very little rain. There is some doubt whether subsoil ploughing is worth the time and labor; but it has a tendency to prevent the land from washing, and saves some weeding by burying the seed of grass too deep to germinate. Professor Mapes mentions land that had been brought up from fifteen to seventy-five tushels of corn per acre by subsoiling. When there is much coarse litter 
to be ploughed in, the land should be flushed with a large plough, and then ridged with a small dagon. Not a foot of land should be put in corn that will not yield five barrels to the acre, and then we may make corn enough and find time for many valuable improvements. When the corn is gathered the stalks should be speedily brought together and stacked or set up with the little end down, and thrown into the pens early in the winter for food and litter. But if food is abundant, they may be buried in the field in the water furrows between the rows where they grew; and in this case it is best not to cut the tops, but pull off the blades. Wheat should not follow corn if it can be avoided.

\section{SEC'TION V.}

\section{WHEAT AND OATS.}

The wheat crop has become more important since our railroads have penetrated almost every section of the commonwealth, and it may finally supplant that troublesome weed, tobacco; and it has an important bearing upon the improvement of the soil. The white bearded wheat, sometimes called the $W$ ard, will stand rust and smut best, but some other varieties are richer in quality and more productive in quantity. I suppose that wheat is 
not indigenous to our climate, as any kind will depreciate, and must be exchanged for a different variety from another part of the world; but this peculiarity does not apply to oats and corn. Forward wheat is not very liable to rust, and it is believed that when the seed is soaked well in brine and rolled in caustic lime it will not be annoyed with that formidable disease now spreading among us, called smut. While wheat will not so well follow corn and be healthy, it does well after tobacco, oats or peas. I sometimes sow a portion of my crop the last of August, and it does well, but I have it grazed hard in the fall and winter to destroy the fly, which to some little extent is apt to get into it. Also the grazing is beneficial to the stock and the treading to the soil, but the stock should not be there immediately after rain or hard freezing. Wheat is generally sown broadcast, but of late a few have introduced the drilling machine, and the land should be well refined and cleaned. Before the ploughs leave the field trenches should be made by dagon furrows on all the slopes to prevent washing. The use of alcohol in harvest is a great mistake; but if any special drink is required, a beverage made of vinegar and water is innocent and palatable. If injury is done by drinking cold water, Dr. Rush advises a teaspoonful or more of laudanum. Wheat when cut should lie two or three days in the 
sun to get thoroughly dried, and then there is no danger of weevil should it remain in stacks until the fall, which is the best time to get it out, both for comfort and convenience. If wheat should take a little rain on the ground, it will not be injured; but oats should be taken up as soon as possible and put in good stacks at once in different parts of the field. It is best to commence seeding oats the last of February if the season will permit.

\section{SECTION VI.}

\section{HAY AND PASTURAGE.}

In Eastern Virginia the sun is too hot for meadow grass to any great extent, and we need our flats for corn, but we should have clover lots for hogs, and also for hay. As an improver, clover will not answer on sandy soils; but herds-grass or timothy should be scattered freely for grazing, and in some locations a meadow might be very valuable if made rich enough to keep out broomstraw. When our flats are scarce they should be liept in the highest degree of fertility; and Low says, "Lands after cropping may be laid down to grass and grazed with constantly increasing fertility; but if suffered to become full of weeds the improvement is slow." The first statement is very encouraging, if true, 
and the last is doubtless the truth when applied to broomstraw. When this is thick we should not turn it in as it is an acid grass, but burn it, and the ashes will give the soil an alkaline character. Every man who would have good stock should have two places for pasture, that he may shift them frequently; and this applies especially to sheep. All stock should be excluded from the common pasture in the spring for several weeks after the warm weather commences, that the grass may get ahead of their wants, and then it will keep ahead. This pasture should include our meanest land, and if the broomstraw is fired in the winter or spring it affords good grazing while tender, but young pines should not be destroyed in the operation.

\section{SECTION VII.}

\section{POTATOES AND TURNIPS.}

Sweet potatoes should be put on soft, sandy land, a little moist, and planted in April. They should be cut into pieces about three inches long, and two pieces put in a hill; but the red may be planted from slips drawn from a hot bed prepared in the month of March. Before digging, a load of dry oak leaves should be provided, and as the potatoes are dug they should be at once taken to the cellars, 
taking care to have the sides well lined with the leaves, and the potatoes covered over with a mass about a foot in thickness; and then you will never have to buy or beg seed. Or you can make a kiln in your field or garden, by elevating the earth about six inches, and after putting on the potatoes put on leaves, boards and earth, and make a rail pen around it and cover it with plank or boards, taking care at the same time to fill the pen with leaves. For expedition Irish potatoes may be planted in the bottom of a deep furrow and covered with straw or stable manure, and then let the furrow slices be reversed and thrown on them; and the planting may be in November or March. Potatoes should have a light weeding with the hoe before the plants appear above the ground, to destroy the young grass; but Irish potatoes need only one thorough working. It is useless to plant them late and expect a summer crop in our climate; but if we plant in the fall or spring we will succeed well, and as we have never seen the rot, we ought to go more into the culture of this cheap and valuable article.

Turnips will not often do well if sown before the first of August. The best of them should be put in kilns in November, and the patch, or portions of it, covered thickly with oak brush with the leaves on, or with leaves from the woods and a little brush without leaves thrown on them, and the turnips will 
improve in the winter and afford early sallad in the spring.

\section{SECTION VIII.}

PEAS, PUMPKINS, ETC.

The pea is getting into high repute as an improver, and is a rich, cheap food for man and beast. The cornfield pea does best planted the last of May or the first of June, and is frequently sown to advantage over the fields of corn when laid by, and on stubble land after wheat harvest. The crowder variety, perhaps, affords the greatest yield, but the large black-eye is preferred by the ladies for the table; and there is a stock pea said to excel for stock and litter. Snaps are now commonly destroyed in the winter by a little bug that generates within them, but this can be prevented by having a late crop for seed, that will mature just before frost; or if bunch snaps, it should be the second crop. Pumpkins and cymlins are well worthy of attention for cattle and hogs, and they can be produced in large quantities with very little labor. The cymlin crop affords good feed for hogs very early in the season when food is apt to be scanty, and they should be fed away while they are soft and can be easily broken. They should be planted early in April, but pumplins in May, in moist land; and they do well 
with corn in the flats. Melons and other vine crops do best in a light, sandy soil, and are often raised with corn or tobacco.

\section{SECTION IX.}

\section{TOBACCO.}

This is the great production of Virginia for replenishing an empty purse, but a rage for it will destroy the face of any country, not because it exhausts our lands, but consumes our time. A full crop keeps us in a race from January to January, and allows no time to attend to lands, manures, stock, or anything else. But what we call a half a crop might be cultivated without much inconvenience : and being, of course, more nicely managed and of better quality, would bring as much money. The plant takes its name from Tobago, an island in the West Indies, and is generally used as a luxury, and often to our injury. Some directions for raising it are taken from an article written by Mr. J. F. Edmunds, Esq. of Charlotte, a judicious and successful planter and farmer, and published in the Farmers Encyclopœedia: "The land for the plant bed is usually selected in a warm place on a south or southeastern side of a hill in a wood, new ground being alvays preferred. From this the roots should 
be grubbed, the rubbish cleared away and the old leaves raked off. Brush of pine or other wood is then to be piled on three or four feet thick, and this is to be set on fire, or a part of it may be fired for an hour or so at a time-proceeding thus over the whole bed. The place is then to be broken up with hoes, and sometimes with coulters drawn by horses or oxen, and the work repeated until the earth is made perfectly fine, being careful to avoid turning under the surface. All the roots should then be extracted and the land laid off in beds 4 feet wide-a little elevated if wet; and to 16 square yards a common pipe bowl of seed is sown." In regard to the cultivation and management, Mr. Edmunds says: "The land for tobacco should be of the best quality, either newly cleared and virgin soil, or old ground highly manured and well pulverized. The culture is very much like that adopted for Indian corn : the plough, cultivator and hand hoe being freely used to keep down weeds and loosen the earth. In about three months after setting out, the plants assume a spotted and yellowish appearance, indicating that they have attained sufficient maturity for cutting and housing. This stage of the tobacco culture is generally reckoned the most difficult and delicate part of the whole business, and the most judicious hands should be selected for cutters. In curing, we commence our 
warming fires the day after housing, and we keep them up from 36 to 48 hours : the mercury ranging from $100^{\circ}$ to $115^{\circ}$. The fires should be kept steady, with a gradual increase of heat to $150^{\circ}$ or $1600^{\circ}$ until the tobacco is cured." But now the purchasers prefer more sun and less fire, which is attended with less danger, and it is a great saving of time and fuel.

\section{SECTION $\mathrm{X}$.}

AGRICULTURAL IMPLEMENTS, ETC.

As our object should be to plough deep, we should select the large dagon called the Livingston, or one similar, as it cuts the deepest furrow and affords the easiest draft to the team-being long and sharp like a wedge. A coulter should not have angles in its shank, but a regular curve, like a semicircle. With a large point it is very useful in dry seasons in cultivating corn and tobacco; but in breaking up new ground, the point should be very narrow. Hoes for grubbing should have no curve in the blade, but be perfectly straight: and the helves should not be round, but a little flattened. We should have a few prong hoes, made with three long tecth, instead of a blade, for digging up long, coarse litter. The pole of an axe should be nearly as 
heavy as the blade, and in grinding it should be held with a firm grip in the hand, that there be no convexity or unevenness in the bevel. I have been surprised to see how few people have their straw cutters in condition for work, so that not only their forage is wasted, but their horses are not half fed. A good corn sheller is an important article to save time when we use much meal for stock: and one sufficient for a small family can be had for $\$ 10$. The best threshing machines that we have seen have, in addition to the common apparatus, a bag open at both ends stretched behind the cylinder to prevent the wheat from scattering, and to throw it on a plank frame below that has holes in the bottom to serve as a riddle, and by a vibratory motion cleans the wheat of the straw, and by the same motion the straw is gradually borne off beyond the dust to a convenient distance for stacking. There should be shelters for ploughs, hoes, \&c., and one with benches and brakes for making gates, ploughs, helves, \&c. in bad weather; and we would say there should be a place for every tool and every tool in its place. 


\section{SECTION XI.}

\section{DRAINING AND IRRIGATION.}

Great injury is sustained all over the country by neglecting to drain not only marshes, but little oozings on the hill sides, and thus the best lands produce less than the poor ridges; but thorough draining makes our fields productive and our homes salubrious. And it is astonishing to see how much surplus muck or rich mould, well adapted to poor land, if dried and pulverized, may be taken from a small place. Many of us have, in this item, an inconceivable amount of wealth; for one of my neighbors has enough in one field to employ a team 100 years, and he has not carried off the first load. It is excellent for corn and small grain, but not so good for tobacco. No farmer ought to have open drains or ditches where they can be avoided, as they occupy some of his best land, soon get infested with briars and bushes, are liable to fill up, and are in the way of his teams in ploughing, so that in turning round they break down and destroy his crops. The cheapest covered drain is made of three pine poles, with the brush thrown in upon them, and then the earth; but to fill up a foot deep with very small stones or gravel is more permanent. Irrigation is not, we think, sufficiently re- 
garded in our ordinary crops. We have vast quantities of water, charged with fertilizing elements, passing on to the ocean under our eye, and we make no effort to arrest them; and as a country becomes more cleared up, it is more sulject to long dry spells, which produce sometimes almost a total failure in the crops. Wherever streams are turned out on grass, stubble, or even any crop, except tobacco and wheat, the improvement is very visible; but especially should it be done in the fall and winter, when practicable, on waste lands, pastures or meadows. No doubt the wisdom of coming generations will invent great improvements upon this branch of our subject. Even our little bill side ditches can be made to empty on waste lands and impart ferility, or in low, boggy places to elevate them and mingle sand with their stiff pipe clays, and improve their texture.

\section{SECTION XII.}

\section{FUEL AND FENCING.}

The majority of farmers should curtail, by onehalf, the surface of their arable land, and let trees and shrubbery take possession, which will both improve the soil and furnish timber for coming generations. Much of our fuel may be obtained from 
decayed trees in the forest, cut and hauled when the land is too wet to be ploughed. But pine does well if kept elevated from the earth, and it affords fine logs for building, if they are hewed on two sides. To save fuel, chimneys should have a throat only four inches deep, and the fire place should be splayed on each side to an angle of about $45 \mathrm{de}$ grees to reflect the heat. Pine, cut for rails, should lie a few months before they are split, that the bark may decay sufficiently to fall off, and they will last longer. Many fences are rather a source of offence than defence; but bad gaps and gates make more bad stock than bad fences. By attending well to these, you can train your stock not to jump a fence four feet high. I was once opposed to what is called the fence law, requiring every man to keep his stock upon his own premises, lest it might bear hard upon the poor; but even upon the score of interest $I$ have made it a law to myself for many years. The most of people suffer more in the loss of stock, time and manure, than the little range is worth. In one respect the poor man would have the advantage in turning his crop out instead of his stock, as it requires more rails to enclose a small field in proportion to the number of acres enclosed, than it does a large one, and this extra expense falls upon the poor man. 


\section{SECTION XIII.}

\section{STOCK RAISING AND FATTENING.}

There is some advantage in a good breed of horses, cattle and sheep, but not much in the breed of hogs, as they improve more by good keeping than any other animals. Our fault is, to keep too much stock ; for, as a matter of economy as well as pleasure, all animals should be kept fat and thrifiy, or not kept at all. A horse that is in the habit of being fat, will not eat as much as a poor one, and will perform more service and sell for about double the price. The corn for feed should generally be ground, but if that cannot be affurded, we should soak it in brine before feeding. Except for purposes of necessity and charity, corn should not be carried from the farm, but fed away to our animals, and after we have enriched our lands by their manure, we can sell them. Mr. J. R. Edmunds truly says: "At the usual range of prices between corn and pork, it is more profitable to feed than to sell." Hogs for pork should not be kept more than 12 or 18 months, and should average 200 pounds. The way to do it is to keep them up in close pens, with plank floors, the most of the year-at least from harvest time until they are killed-ihat they may have nothing to do but eat 
and sleep; but they should have salt and ashes once a week, and occasionally copperas and sulphur. I once had a pen of hogs so surfeited by heavy feeding with corn when first put up, that they all contracted a liver disease, which checked their thrift and diminished their weight about one-half; and therefore great caution should be observed to keep them hearty and healthy with a proportion of light diet; and the slops should be kept in a swill tub and made sour. If we can dispense with balf our tobacco and make as much money by it, we can certainly raise pork, beef, mutton, horses and mules for all our markets and mechanics. Sheep can be raised with very little expense, but they require regular attention and a little salt twice a week. Wet pastures do not suit them, and they should stay in no place more than a month without a change of locality.

\section{SECTION XIV.}

THE WAY TO WEALTH.

We will conclude our treatise on agriculture by some extracts from the essay of Dr. Franklin, entitled "The Way to Wealıh."

"It would be thought a hard government that would tax its people one-tenth part of their time, to 
be employed in its service; but idleness taxes many of us much more, if we reckon all that is spent in absolute sloth, or in ille employments or amusements that amount to nothing. Sloth, like rust, consurnes faster than labor wears, while the key often used is always bright, as Poor Richard says. But dost thou love life? then do not squander time, for that is the stuff life is made of. How much mote than is necessary do we spend in sleep? forgetting that the sleeping fox catches no poultry, as Poor Richard says. Lost time is never found again, and what we call time enough, always proves little ennugh. He that rises late must trot all day, and will scarce overtake his business at night. Drive thy business and let not thy business drive thee, as Poor Richard says. And again, there are no gains without pains, then help me iny hands, for I have no lands. At the working man's house hunger looks in but dares not enter. Nor will the sheriff or constable enter; for industry pays debis, but despair increaseth them. Then plough deep while sluggards sleep, and you will have corn both to sell and to keep. Work while it is called to-day, for you know not how much you may be hindered to-morrow. If you were a good servant, would you not be ashamed that your master should catch you idle? then be ashamed to catch yourself idle. Handle your tools without mittens, for the 
cat in gloves catches no inice, as Poor Richard says. Methinks I lear some of you say, "Must a man affurd himself no leisure?' A life of leisure and a life of laziness are two things. Leisure is time for doing someting useful; this leisure the diligent man will obtain, but the lazy man never.

"So much for industry, my friends; but to this we must add frugality if we would make our inclustry successful. A man may, if he knows not how to save as he gets, keep his nose all his life to the grind stone, and die not wo:th a groat at last. A fat kitchen makes a lean will, as Poor Richard says.

"And many estates are squandered by getting, Since women for satin cease spinning and knitling, And men for whisky their hewing and splitting."

"What maintains one vice would bring up two children. Beware of little expenses; a small leak will sink a great ship. Who dainties love, shall beggars prove; and again, fools make feasts and wise men eat them. Buy what you need not, and ere long you must sell what you need. A ploughman on his legs is higher than a gentleman on his knees. Pride took breakfast with Plenty, dined with Poverty, and supped with Infamy. For poverly often deprives a man of all spirit and virtue. It is hard for an empty bag to stand 
upright, as Poor Richard says in his Almanack. This doctrine, my friends, is reason and wislom; but after all, do not depend too much upon your own industry, frugality and prudence, though they are excellent things, for they may be blasted without the blessing of Heaven. Therefore, ask that blessing humbly, and be not uncharitable to those that at present seem to want it, but comfort and help them. Remember Job suffered and was afierwards prosperous." 


\section{PART II. \\ ME D I C I N E.}

Presuming that Cutler's Anatomy' and Physiology, or something equivalent, has been studied by the classes, we would offer this short and inperfect treatise on the practice of medicine. Dr. Rush says, "Nurses and old women often suggest facts in the history and cure of diseases, which have escaped the most sagacious observers of nature." But still there ought 11 be great caution and deliberation observed in offering prescriptions, as life is at stake. A wise and prudent man in this way may do a great deal of good in imitation of Christ, who introduced his mission by "healing all manner of disease among the people;" and missionaries find it necessary to carry with them a knowledge of the healing art, as well as other arts, to overcome the prejudices of the heathen. 


\section{SECTION I.}

THE PREVENTION OF DISEASE.

In the first place, we would say that we should endeavo: so to live as to let medicine alone. My grandmother lived to be upwards of ninety years old and raised a large family of children, and never spent a doliar in paying physicians' bills; but she had a good constitution and led an active life. The old adage is true, "An ounce of prevention is worth a pound of cure." A temperate man may be much exposed to weather or breathe pestilential vapors and yet escape unhurt, while a gross feeder will take cold in the best weather, or die of a fever when there is no epidemic. 'The stomach is the great source of disease and debility, as well as of health and vigor. By regarding premonitory symptoms, many diseases in their incipient stages may be starved out, by light diet with good exercise. Observe in yourself the effect of your daily meals and other indulgences, and act accordingly, and you may soon become to a great extent your own physician. Dr. Franklin says, "If after exercise we feed sparingly, the digestion will be easy and good, the body lightsome, the temper cheerful, and all the animal functions performed agreeably. Sleep when it follows will be natural and un- 
disturbed; while indolence with full feeding occasions nightmares and horrors inexpressible." We should not only regard the quantity but the quality of the food and the manner of eating. Half cooked meat, close tough bread, hot coffee and fast eating are injurious. A free use of tobacco immediately after eating and the use of ardent spirits are calculated to destroy the tone of the digestive organs. Thus, by ignorance or wanton indulgence we suffer pain, lose our time, incur expense, weaken our energy of body and mind, and hurry ourselves to an untimely grave. But after all necessary caution and care, so little knowledge and power have we, that diseases will come, and we should all possess some knowledge of the healing art ; and as a good general rule, it is said we should keep the bowels and pores open, the head cool, and the feet warm. But diseases are so numerous, symptoms are so various, and constitutions so different, that we must not only be close observers, but consult the best judges and draw our resources from the wisdom of ages. We should not be deterred from this important duty by a few hard words; for they generally signify very simple things. 


\section{SECTION II.}

\section{PATHOLOGY.}

Pathology is derived from two Greek words, pathos, feeling, and logos, a discourse, and signifies a discourse about feeling pain, or in other words about the causes and symptoms of disease. But before we enter upon the subject, we would say the science of medicine has been studied in all ages of the world, and was reduced to a system by the Greeks and Romans, and the terms they used have been transmitted to us, and are still in use as most appropriate; and if we are not acquainted with the dead languages, we can learn the signification of the terms in a dictionary or glossary. Says Homer, in the Iliad:

"A wise physician skilled our wounds to heal, Is more than armies to the public weal."

It is a little remarkable that Ewell's Medical Companion, written nearly fifty years ago, and supposed by some to have become too antiquated for the present day, describes the diseases of the past year or two with great exactness. He says: "During the winter and spring, pleurisies, pneumonias, quinsies, rheumatisms and inflammatory fevers pre= vail. Toward the end of summer and in autumn, intermittent and remittent fevers, with dysenteries 
and putrid ulcerous sore throats, make their appearance." We have had the most of these in our family and neighborhood, and many of our friends have been taken off by the dysentery, which has become the most formidable of all our maladies. Pathology may also be defined morbid anatomy and physiology, as it implies a derangement in the solids or fluids of the animal economy. But to be more particular, it embraces, 1st nosology, (from nosos a disease, and logos a discourse,) which signifies an account of diseases and of their differences; $2 \mathrm{~d}$, ætiology, (from atia a cause, and logos a discourse,) signifying an account of the causes of disease; $3 \mathrm{~d}$, symptomatolngy, (from symptomata symptoms, and logos a discourse,) signifying an account of the symptoms of disease; 4 th, therapeia, (from therapeuo to heal,) implying the proper treatment of disease. Skill in this department is called diagnosis, (from dia thoroughly, and gnosco to know,) signifying the ability to distinguish different diseases; and while it is very important, it is very difficult as implied in the proverb, "A knowledge of the disease is half the cure." And prognosis is the ability to prognosticate or foretell the final result. Diseases may be either structural or functional, the first relating to diseased organs, and the second to diseased action. Mistakes are often made by supposing a disease is located where the pain is, when it is the 
effect of sympathy with the diseased or disordered organ, which is less sensitive. Thus, a disordered stomach is often not felt in that region, but is followed by a severe headache, or by pains in the limbs and general debility. Diseases also have remote and proximate causes which require careful consicleration. Diseases are either acute or chronic, intermittent, remittent or continued.

\section{SECTION III.}

\section{THE TREATMENT OF DISEASES.}

It seems f.orn Dr. Chapman's remarks on the nature of life, that "Every living body, animal or vegetable, is endowed with a primordial principle of life, and which, being resident in the ova of animals and the seed of plants, constitutes the power by which in the first place the various organs are moulded, developed and perfected, and by which afterwards the animal ecomomy is defended against the action of mechanical and chemical laws." There is a diversity of opinion as to what element of nature constitutes the principle of vitality, but I presume from the experiments of Galvani upon a dead frog, which gave rise to the science of galvanism, and similar experiments since made upon human bodies, that it is the electric fluid. This ap- 
pears to be the connecting link between matter and mind, flesh and spirit, and is ersployed by the spirit to carry out the volitions of the mind through the nervous system. There is also a difference of opinion concerning the operation of medicines, the most of modern writers supposing that their inpression is extended through the system by sympathy, and others have thought they entered into the circulation, and thus by a sort of chemical action, they correct the vitiated condition of the fluids. This last view of disease and curative agents is called the humoral pathology; but it is not so important to know the modus operandi as the ficts. Dr. Elliotson says: "It is ordained by Providence to a great extent, that the injurious causes to which we are exposed should have but a temporary effect. Either the body has the power of resistance or the causes exist temporarily; either from being applied but temporarily to the body, or from being able to exert no more than a temporary influence. This power of the body to shake off its morbid state is called by writers vis medicatrix natura, the curative power of nature. For example, when acrid matters are taken into the stomach, the stomach has a tendency to reject them; or if they be passed through the stomach into the intestines, the intestimes are excited to action, and they are got rid of." He also says: "In the treatment of many diseases, as well as in their prevention, we act ra- 
tionally; we proceed upon general principles; and the whole treatment is in the highest degree philosophical. We make an accurate diagnosis in the first instance; we then see what is wrong in the state of the system, and employ such means as are evidently calculated to remove that state. But in certain diseases and in certain varieties of disease we are obliged to act empirically-to act in a certain way without knowing why we are likely to be successful. The treatment of ague, of itch, and of syphilis is empirical, for it is impossible to know why a ferw grains of sulphate of quinine will cure ague, why a few grains of sulphur will cure the itch, and why syphilis will cease sooner if we exhibit mercury than if we do not." He says moreover, that "A disease may appear evidently to point out the necessity of a certain mode of treatment, but a peculiarity of the individual relating to particular articles of fool, or in relation to the presence of some other disease, may render it exceedingly improper.

\section{SECTION IV.}

GASTRITIS.

The word gastritis is derived from gaster, the stomach and itis inflamation, and signifies an inflammation in the stomach. As the digestive organs take the lead in giving life, health and vigor to the 
system, we will first consider diseases connected with them and the remedies. Dr. Gregory remarks that "the pathology of the mucous membrane of the alimentary canal is a subject of great extent and importance; but it has not yet been investigated with all the accuracy which it deserves. While some parts of it are well understond, other's are involved in a degree of obscurity, which it will require a long course of observation to clear up. One of the most obvious of its general principles, is the great liability of the membrane to inflammation. Such an affection occurs both in an acute and chronic form, as idiopathic and as supervening on other diseases in adults and in children. There appears to be a peculiar tenderness and susceptibility of inflammation in this membrane during the first years of life, and this points out the great importance of regulating the diet of children with the most scrupulous care." As the circulation of the blood is more rapid in children, they must eat more frequently than adults, but they are more liable to disease, both from the tenderness of their organs and their indiscretion, and parents should be their watchful guardians upon this vital point. The brutes have an unerring instinct to guide them in taking the proper quantity and quality of food, but fallen man has no presiding divinity within him to keep him from destruction, and consequently thousands 
of children of vigorous constimtions are cut off by the ignorance or neglect of their parents; or rather by excessive kindness and indulgence. Gastritis is characterised by constant pain in the pit of the stomach, attended with nausea and vomiting, and sometimes will great heat and thirst. It may proceed from anything calculated to irritate the stomach by cating or driuking, or from sudden enotions of the mind. Leeches should be applied, but the stomach should be kept as quiet as possible, and the bowels kept open hy injections. It frequemly occurs in connection with erysipelas, and is sometimes evanescent, and will go away without treatment if we keep the patient low.

\section{SECTION V.}

\section{ENTERITIS AND COLIC.}

This word comes from cnteron, an intestine, and signifies an inflammation of the ilium or small intestines. It may proceed from irregular habits of life, from cold or wet, or may follow measles, consumption or continued fever. Colic is spasm, with the pulse natural and the pain irregulor, but in this, the pain at the navel is constant, although not of uniform intensity, and there is great costiveness. The pulse is hard or wiery, and there is nausea and vo- 
miting. The pain is increased by pressure, but in colic it is relieved by it. We must bleed from a large orifice without mercy, corer the abdomen with leeches and exhibit large closes of calomel if there is strength in the patient. But the disease may proceed from hernia, and require different treatment. A drop of croton oil every two or three hours is good, or oil of turpentine and injections. As colic is nearly of the same character, it may also be treated much in the same manner; but opium may be combined with the calomel. In mild cases mint or ginger tea or a glass of brandy will give relief, and hot bath or flannel wrung out of hot water applied over the abdomen. Bilious colic may proceed from acid and indigestible fond, and is apt 10 occur at the same time with diarrhea, cholera and jaundice, and may be fairly imputed to an increased and vitiated secretion of bile. Rubbirig laudinum on the abdomen or applying a blister has a decided effect, when through irritability the stomach rejects medicines.

\section{SECTION VI.}

DYSENTERY.

It appears that the principal seat of this formidable disise is the inner membrane of the great intes- 
tines or colon. In general it appears to be the effect of hot, dry summers and marsh effluvia, and among us has been more malignant in low, marshy regions, and attended frequently with remittent fever. "In this case," says Dr. Potter of Baltimore, "the remittent is the epidemic, and it occurs in the autumn. This is usually a more inflammatory fever, and requires a more vigorous procedure to cure it. It is always accompanied with a congested state of the liver, and frequently by a suspended secretion of bile and obstinate constipation of the intestines." Dr. Colhoun says, "Dysentery is distinguished from diarrhoea by the tenesmus, bloody stools and general fever, which characterizes it." Dr. Elliotson says, "In it there is spasm and inflammation together, and both obstruction and purging. The term dysentery derives its character from dus, bad or sickly, and enteron, an intestine. In addition to hot weather and bad air, bad food and bad water have a tendency to produce it. Last summer I stated to an aged physician in one of the lower countics, where the disease was raging, that I did not like the water there, and thought it had a bad influence on the health; but he said he did not believe water had much to do with health. Dr. Elliotson says, "It is undoubtedly produced sometimes by bad food and likewise hy bad water." But perhaps the greatest danger arises from excessive eat- 
ing and drinking, and thus deranging the functions of the liver. With regard to the cure, physicians differ very widely, and all remedies sometimes fail in very violent cases. I enquired of a young physician a few months ago concerning his mode of treatment, and he told me his first object was to lock up the bowels; and he lost most of his patients. Dr. Stephenson of Baltimore says, "It is like locking the thief within the house to do all the mischief he can." When there is much fever, blood letting is important, and the exhibition of calomel combined with opium; but some physicians consider mercury in any form dangerous, and prefer castor oil, spirits of turpentine, \&c., together with anodyne injections. I have seen no physician who uses emetics in this disease; but $I$ have seen the happiest effects result from them, and they are recommended by Dr. Akenside.

\section{SECTION VI.}

\section{DIARRHGEA.}

By diarrhœe (diarrheo to flow through) is meant frequent liquid and rather copious feculent stools. In dysentery the stools are not feculent, but sometimes of a pitch-like substance. Sometimes, instead of a mucus, there is thin serum; and if we procure 
a passage, the discharges are in hard lumps, and the pain is constant; but in diarrhoil there is pain only at the time of evacuation, and the discharge is of all colors. Dr. Elliutson says "The causes of this disease are, in the first place, too much food. If a person eats a great deal, it must find its way out, and it does. 'Tinere must be more exportution in proportion to the importation, so that diarthoea is a proper effort of nature to get rid of it. Mularia is enumerated among the causes, and cold after heat, and sometimes it follows measles. As to treatment of this disease, if it be slight, it is best to do nothing at all, and take no exercise; but if it run on, various opiates and astrungents are given; and I have found by experience that a little calomel or blue pill is the most certain and speely remedy. Diarrhoea, dysentery, enteritis, colic and cholera are artificially distinguished by the state of the alvine evacuation principally; but as they all result from disturbed function of the intestinal canal, there is an intimate pathological affiuity.

\section{SECTION VII.}

CHOLERA.

This dreadful disease appears as yet to be confined to the cities and large water courses, and 
seems destined to baffle the best medical skill and set at naught the wisdum of man. The best course perhaps will be to avoid the exciting causes, such as crucle and indigestible fruits, cold and moisture, suppressed perspiration, acrid medicines and marsh miasmata. 'The cholera (firom chola bile, and reo to flow) is characterised by a sudden attack of bilious vomiting and purging, with spasms and severe pain in the abdomen and calves of the legs, and in very bad cases, in the neck and back. Fifty drops of laudanum may be given in the first instance, and repeated to the extent of ten or fifteen drops every quarter of an hour; but Dr. Colboun says, "The opium should be combined with calomel and given every two hours, or with a saline effervescent draught in the form of laudanum; and if still rejected, it may be given in the form of enema, giving two grains each time. The nitric and sulphuric acids, combined with cascarilla, chamomile or columbo tea, often arrest the vomiting. A heated plate, bags of heated salt or sand, cloths wrung out of hot water applied to the stomach, frictions of laudanum over the abdornen and limbs ; a cataplasm of opium over the stomach; a mustard poultice or blister of cantharides to the epigastrium; nitric acid applied over the surface with a feather, and when its action has been sufficient, neutralized with carbonate of potass to prevent its spreading, 
are the remedies." This should be accompanied with a diet of broth or beef tea to dilute the depraved secretions in the intestinal canal. If the pulse is feeble, wine or brandy may be necessary, and a warm bath or hot bottles to the feet.

\section{SECTION VIII.}

\section{HEPATITIS.}

This word is derived from heper, the liver, and signifies inflammation in that organ, and it lies at the foundation of many diseases. It is very common in the southern states among white people, who are apt to diet freely and drink spirituous liquors, and live in idleness. In England it is so often observed among the intemperate that it is called a gin liver. But in a chronic form it is very troublesome to students, who indulge their appetite for food and tobacco, and take but little exercise, as I know by experience. But after many years of suffering and blundering in blindness in regard to the cause and cure, I have learned to live comfortably, by a proper attention to diet and exercise. It has been remarked that the liver in warm climates seems to be the seat of disease nearly in the same proportion that the lungs are in cold regions; and I find I always suffer more as the spring opens and 
the weather gets warm. But as the lungs are in the vicinity of the liver, and in close contact, it is reasonable to believe that consumption may follow as the consequence of a liver affection by sympathy with persons predisposed to it. I think I have seen such cases, but writers, I believe, say nothing about it. Dr. Potter, however, gives an intimation upon the subject in these words: "The inflammation spreads from the liver to the diaphragm, and along the pleura pulmonalis-the pus discharged by the bronchia passes through the channel occasioned by inflammation into the lungs, and not (we judge) by the direction of the vis medicatrix through the lymphatics." Hepatitis often ends in jaundice. "If the dixts become thickened by chronic inflammation," says Dr. Elliotson, "if they become hypertrophied, their canal may be so much diminished that the bile cannot pass, and consequently we have jaundice." Gout and rheumatism and many cutaneous affections also follow a derangement of the digestive organs with persons of full habits. There is a most intimate connection between the stomach and liver, as we may observe in the digestive functions of brutes as well as ourselves. Year before last I had a pen of fattening hogs very much injured by a heavy surfeit of corn, and when they were slaughtered every liver was ulcerated and nearly destroyed. Last year I was strict to guard. 
against the evil, and every liver was sound. A slight attack of hepatitis may be removed by attention to light diet, but calomel or blue pill commonly acts like a charm when the disorder is serious.

\section{SECTION IX.}

CONSUMPTION OR PHTHISIS.

It seems hardly necessary to say anything about this dreadful scourge of the human race, as it is considered generally incurable, but no doubt something may be done to prevent its occurrence. It exhibits two forms, one with tubercles on the lungs, and the other with abcesses; but the distinction does not amount to much, as they give rise to nearly the same train of symptoms, and often coexist. The symptoms are well known to be a fixed cough, a difficulty of breathing, hectic fever, night sweats, and emaciation, spitting of blood, \&c. Dr. Colhoun says, "Consumption has been arrested by the supervention of other diseases, as abcesses and mania, facts which render probable the efficacy in this disease of extensive drains on the surface of the body." I had a female friend who had it for years, if the diagnosis of skillful physicians could be relied upon, and during the time she for a few months improved very much, and regained her 
flesh, but a combination of domestic afflictions and other circumstances aggravated it, and she finally diecl. I should suppose then that large blisters, issues and seatons, and very spare vegetable diet, and other similar means, might save many cases if taken in hand early.

Lænnec relates ten out of many cases of the tubercular consumption which had been cured; but Dr. Baillie states that after the practice of a long life, he knew only one or two. Fresh air, a uniform temperature, warm clothing and moderate exercise are very important. Dr. Rush often cured it by a slight salivation, after using the antiphlogistic plan. Actœa racemosa has been used by Dr. Garden of Virginia, in this disease, with great success. Liebig says, "Hepatic diseases arise from excess of carbon, pulmonary diseases from excess of oxygen.

\section{SECTION $\mathrm{X}$.}

PNEUMONIA AND PLEURISY.

Pneumonia, from pneumon, a lung, is a very common and dangerous disease, and it is thought to be an inflammation in the air cells. The symptoms resemble those of consumption, and the treatment in the main should be the same, especially venesection from a large orifice, cupping \&c., and 
they should be promptly used, lest a foundation be laid for consumption. I have seen salivation have a good effect, and emetics are recommended, together with sinapisms and warm diaphoretic drinks. Pleurisy is a disease of the pleura, a serous membrane investing the lungs, generally attended with a hard, quick pulse and pain in the side. There is no crepitous rattle heard on listening at the affected part, as in pneumonia, and no sibilous rattle as in bronchitis, and the respiration is rapid. Bleeding, mercurializing, purging and starving will cure it just as easy as any other inflammation; and to them may be added digitalis and colchicum in a saline mixture, with an excess of alkali to keep down the action of the heart and arteries, and to determine to the kidneys and skin.

\section{SECTION XI.}

\section{BRONCHITIS AND ASTHMA.}

Bronchitis (from bronchos, the windpipe) is an inflammation of the bronchia or branches of the windpipe, at the lower end, which enter the lungs. The windpipe itself is called the trachea, and the upper end, that opens into the mouth, the larynx. Diseases in those parts are called tracheitis and laryngitis, and in children tracheitis is called croup. 
Bronchitis is sometimes mistaken for asthma, which comes from asthmadzo, to gasp for breath; is a spasmodic affection of the organs of respiration, attended with wheezing. A slight affection of these organs is called a catarrh. As bronchitis is very prevalent ainong our presbyterian clergy in particular, I should think it did not result from preaching mainly, but from study and sedentary habits; for "Dyspepsia and diseases of the liver," says Dr. Gregory, "are often attended by the common symptoms of chronic bronchitis." As in other pulmonary affections, blisters and aperients may be necessary if circumstances justify them, and a uniform moderate temperature, warm clothing and light diet are indispensable. Dr. Elliotson says, "Diuretics and emetics are of the greatest utility, and it is a good practice to combine digitalis and squills." It is said that croton oil, rubbed externally on the throat, so as to produce an eruption, will effect a cure. Asthma in the main is treated in the same way.

\section{SECTION XII.}

PALSY, EPILEPSY AND APOPLEXY.

Paralysis is the result of that state which, in the first instance, is apoplectic, and frequently begins 
with coma or apoplexy, but commonly affects either one side or the lower half of the body. The cause may be a mere fullness about the head, and sometimes there is found a serous effusion in the brain, or an effusion of blood. If the disease appear to be of an inflammatory nature-if the head be hot, attended with pain and delirium, then common antiphlogistic treatment should be put in practice, such as bleeding, purging, leeching, mercurializing, applying cold and starving the patient; but we must be on our guard not to go too far. A lady of my acquaintance, who was deranged for many months, was cured by pouring a quantity of cold water on her head. Iodine will act as vell as mercury; but it is only proper when rubbed in as an ointment, or given internally in combination with potassa. If there is great debility, tonics and good food may be employed. Insanity, as Dr. Elliotson remarks, is no doubt a corporeal disease, connected with the pathology of the brain; and when medicines or other diseases counteract the determination of the fluids to the head, they recover. Physicians mention cases where recovery occurred a few hours before death; and I had an uncle who was exactly a similar case, who had lost his reason by epileptic fits. In epilepsy the cerebellum (the little brain) is more particularly diseased, but is often connected with the disease of the stomach, liver, intestines, heart and lungs. 


\section{SECTION XIII.}

MANIA, NEURALGIA, ETC.

It is well known that drinking ardent spirits intemperately produces mania, and that eating hearty suppers will bring on nightmare and other horrors : and, of course, abstinence is the best remedy. But, with the poet, thousands can say:

"I see the right, and I approve it too,

I hate the wrong, and yet the wrong pursue."

It is hardly possible to mark the boundaries of reason and insanity in every case, as there is every grade of genius, from the moping idiot or raving maniac to the greatest philosopher; but as mental operations depend much upon corporeal function, much may be done by us to reaken or strengthen the mind. A sound body is apt to make a sound mind, and we may say invariably does; but bad health, mental anguish, and other causes, have filled our lunatic asylums to overflowing, and yet many are left behind upon the hands of their friends. Neuralgia is an affection of the nerves, and is not very well understood. It sometimes proceeds from a disordered stomach, and emetics, cathartics, \&c. are beneficial. Dr. Jackson of Boston has given cicuta (hemlock) with good effect. When there is no inflammation, stimuli may give relief. 


\section{SECTION XIV.}

\section{IROPSY AND STRANGUARY.}

Dropsy is caused by excessive drinking, poor diet, immoderate bleedings and salivations, and sometimes by scirrhous tumors of the liver or abdominal viscera. It has been said with much truth, that dropsy is rather a symptom of disease than a disease itself. There is always a process of exhalation and absorption going on through all the tissues of the animal body, in addition to the circulation of the blood, and whatever disturbs the equilibrium is calculated to produce dropsy; but as the blond vessels have a great agency in it, they should he supplied with the proper quantity and quality of the vital fluid. Nature makes, to some extent, a kind provision for our irregularities and the influence of seasons. In warm weather, when the perspiration is abundant, the urine is concentrated and scanty; in winter, it is strikingly augmented; and when this secretion is disturbed by the presence of bile, the urine is deeply tinged, and often stranguary is the consequence. This commonly attends only people whose powers of digestion are feeble and their teeth bad, if they indulge their appetite for food and take but little exercise. I had a case of dropsy cured in my family mostly by leeching and 
starving; but if there is great debility, tonics and nourishing food should be given, and especially garlic and onions. Exercise is of the greatest importance when not carried to fatigue.

\section{SECTION XV.}

RHEUMATISM AND GOUT.

Bellonious, a physician who suffered much from rheumatism, is said to have been the first who made an accurate distinction between these diseases. Rheumatism may occur in an active or passive form, and the two varieties require very opposite treatment. There is commonly pain and swelling in the large joints, as ankles, knees, hips and shoulders, and I now have it in one of my shoulders. Dr. Elliotson says: "There is, I believe, but one existing cause of the disease, and that is the application of cold, or cold and wet ;" but in our case it proceerls from derangement of the digestive organs-a cause which Dr. Prout admits, and which I have often known to produce it-and it occurs without the least exposure. When this is the case, we must direct our attention to the stomach and liver. Mercury appears to be equally useful in both kinds of rheumatism, and in the chronic a grain of stramonium (thorn apple) acts well. Gout affects the smaller 
joints, as the toes, feet, \&c., and is very severe. Sydenham, in writing of his own sufferings, compares them to the gnawing of a dog. It generally occurs with robust people of full habits. To cure it, the patient should be very abstemious and take exercise. Colchicum (meadow saffron) is the best medicine, it is thought, and friction is useful.

\section{SECTION XVI.}

INTERMITTENT AND REMITTENT FEVER.

An intermittent fever will cease entirely at intervals and recur again, and is understood to be the effect of malaria; but it is often dependent upon exciting causes more or less under our control. If the return of its paroxysms occurs daily, it is called a quotidian; if every other day, it is termed a tertian. Some years it is very prevalent on our streams, and quinine or oak bark is the best remedy to be used in the time of the intermission or ague; but emetics or purgatives should first be given. And change of location is very necessary. The remittent or bilious fever undergoes somę relaxation of severity at certain periods, and requires more prompt and energetic measures of depletion, and conmonly blood-letting. Calomel is the most efficacious cathartic. This and the yellow fever have a resem- 
blance, and are both extinguished on the approach of cold weather. But they have been awfully fatal, particularly the latter, during the past season, on our western waters. Our best hope is in avoiding excesses in eating and drinking, and needless exposure to hot sun and night air. Dr. Colhoun says, "We should avoid both great abstinence and intemperance, and eating and drinking improper food, as acids, rich sauces, pies, and high seasoning in excess."

\section{SECTION XVII.}

\section{CONTINUED FEVER.}

Continued fever has but little deviation to the end, and there is quickness and smallness of pulse, heat, thirst, high colored urine, costiveness and dry skin. This was a fatal disease among us the last season. If great symptoms of debility appear it is called typhus, from tupho, to smoulder. Sometimes there is great nausea and loathing of food, and at other times a voracious appetite. Dr. Satterly mentions the case of a boy that would eat at one meal a pound and a half of beef steaks or a couple of rabbits without satisfying his appetite; and I have known them stealthily to eat the candles left in the room with them. It is said to be a disease in the glands of the small intestines, and being so far re- 
moved from the stomach leaves it healthy, and by a degree of inflammation sometimes rnakes it more craving. Ventilation and cleanliness are indispensable, and chloride of lime should be sprinkled over the room. Blood letting, purging and vomiting are generally necessary; but if there is diarrhœa, astringent medicines should be used to some extent; and the blue pill then is preferable to calomel. And strong beef tea is a good article of diet, together with Madeira or Port wine. This type of the disease is most generally denominated typhoid fever.

\section{SECTION XVIII.}

SCARLET FEVER AND MEASLES.

Till the close of the 18th century these diseases were considered the same, or two varieties of the same disease; and the same mistake has recently been made by some of our physicians, when the measles first appeared among us; but the scarlet fever among children has been much the most fatal. About a year ago 15 died in one neighborhood not far from us; and one man who had four, lost all. An emetic is generally good, and gargling pepper in the throat, and the patient should have fresh air and be kept cool and clean. Leeches about the throat are preferable to a blister. In 
measles it is only necessary to keep the bowels open with occasional cathartics, and the skin moist with teas and the warm bath. But there is great danger after getting well, lest cold be taken and the lungs become inflamed, and death ensue. Many deaths have occurred within the last year or two, among young people, from this heedlessness.

\section{SECTION XIX.}

THE PEPPER SYSTEM.

As some people prefer the Thompsonian practice, we will give a synopsis of the system :

No. 1 is composed of lobelia inflata, as Linnæus calls it, and is a very efficient emetic. Three teaspoonfuls of powder put into pepper tea and sweetened with brown sugar, is a dose.

No. 2 is cayenne pepper simply, to be used in almost every stage of the remedial process, to stimulate the languid functions, particularly before and after steaming.

No. 3 is called composition, and composed of $\frac{1}{4}$ th of bayberry (myrisa cerifera) root, or sumach (rhus glabrum) root or the berries, $\frac{1}{4} \mathrm{l}$ h of the inner bark of the hemlock or poplar bark tree, $\frac{1}{8}$ th of ginger, $1-16 \mathrm{th}$ of cloves and $1-16 \mathrm{th}$ of pepper. This, taken in large quantities, is a powerful diaphoretic, to be used while steaming. 
No. 4 is poplar bark tea, with pepper and spirits, to be used as a tonic bitter.

No. 5 is called peach syrup, made of kernels from peach seed, poplar bark and bayberry bark, all boiled together, with the addition of sugar and brandy. This is considered as strengthening to weak patients.

No. 6 is composed of pepper, myrrh and spirit of brandy, and is a powerful expectorant and stimulant.

No. 7 is American senna, (cassia marylandica,) half an ounce, sage half an ounce, and ginger a teaspoonful, and steeped together fifteen minutes and sweetened with sugar. Half that quantity is taken as a dose on going to bed; and it is considered a most efficient cathartic. But an emetic of lobelia should first be given to cleanse the stomach; and it is given in broken doses every two hours to relax the system and promote perspiration. The steaming is effected by putting hot rocks into a tub of water, and placing the patient over it wrapped up in blankets while taking the tea. 


\section{SECTION XX.}

\section{HYGEIAN ECONOMY.}

In regard to exercise, some feel best to walk or work immediately after eating: others should be still for about an hour. And in regard to diet, let every man judge for himself what article suits him; for what is one man's meat is another man's poison; but the stomach by indulgence is often like a spoiled child, and does not know its real wants. And stimulating food and drink injures the tone of the stomach and lays a foundation for diseases of body and mind. A teaspoonful of laudanum or more is a good remedy for cramp after drinking too much cold water. For a cough or cold, make a decoction of the leaves of the pine tree sweetened with loaf sugar, and drink it warm when going to bed at night. To cure a sore throat, take a glass of olive or sweet oil and half a glass of spirits of turnpentine, mix them well together, rub it on externally, and wear flannel around it. The Journal of Health says: "When a child is taken with croup, instantly apply cold water or ice water if possible, suddenly and freely to the neck and chest with a sponge." Dr. Rush says : "Worms are a provision by nature to consume the superfluous aliment which all young animals are disposed to take; but calomel in large 
doses with jalap is a powerful and safe anthelmintic." For asthma, slake quick lime in tar water and drink twice a day. For the cure of dysentery, take sweet gum bark, green or dried, steep it in water, sweeten it with brown sugar and drink it freely, and if necessary, add to it a little brandy. 


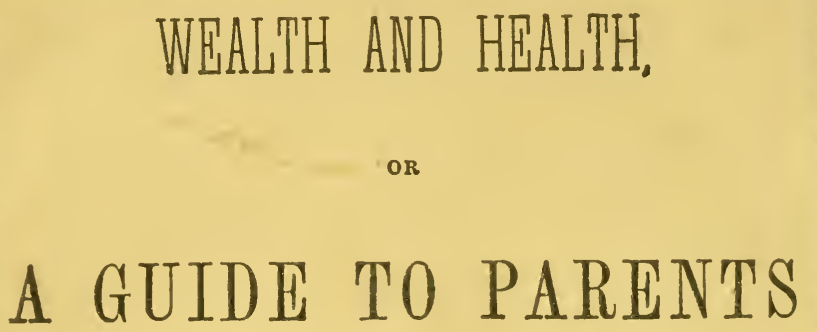

IN THI

\title{
EDUCATION OF CHILDREN.
}

PREPARED FOR THE USE OF SCHOOLS AND FAMILIES.

\section{BY REV M. W. JACKSON,}

\author{
CHARLOTTE COUNTY, VA,
}

"It is certainly of more consequence to a man that he has learned to govern his passions, to be just in his dealings, to be temperate in his pleasures, to behave with prudence in all his affairs, than to be master of all the arts and sciences in the world besides." - FraNki.IN.

"Labor improbus vincet omnia."-VIRGIL.

\section{R I CH MOND :}

RITCHIES \& DUNNAVANT, PRINTERS.

$$
1854 .
$$










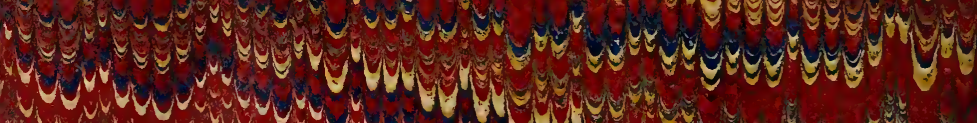
cun a 4 .

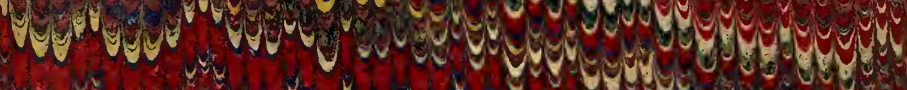

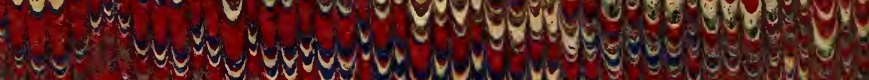
wine we are

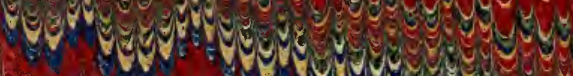
ave ave

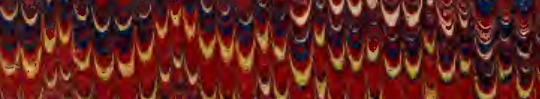
a $\quad$ and w Wo Would Mon co 
Yeve

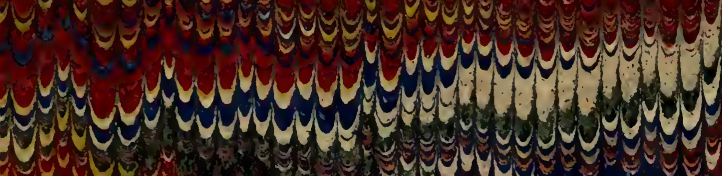
Ju

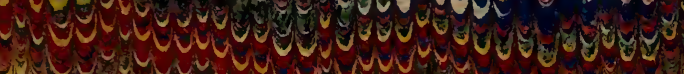
H. E Con

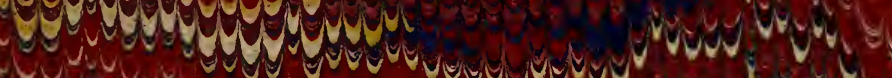
Cuco te

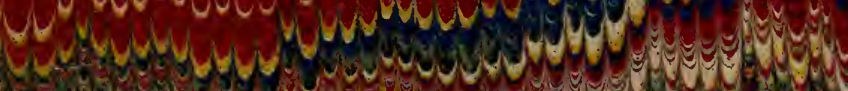
a 2 - J

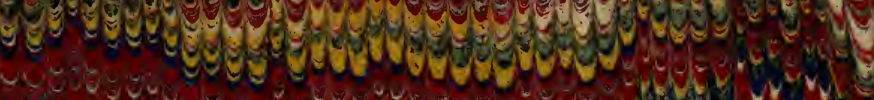

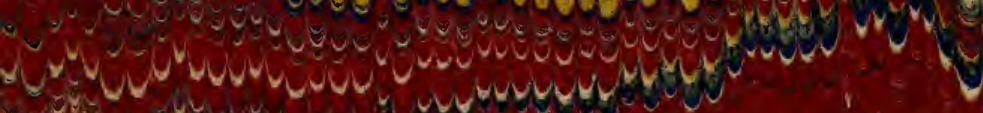

a

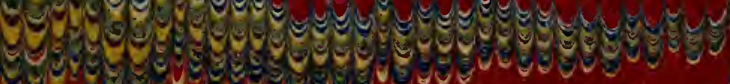
or

y Nives Wre W

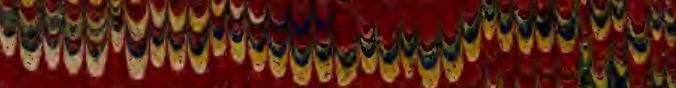
Sinur

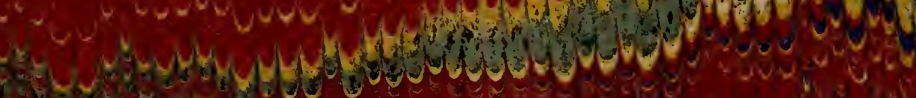

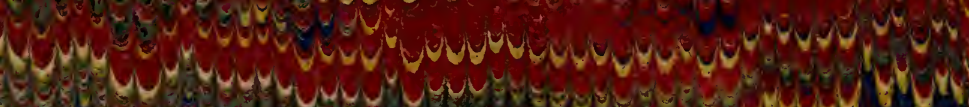

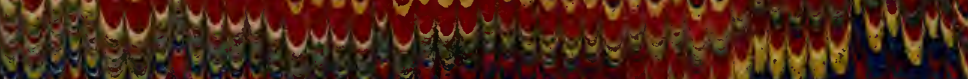




\section{LIBRARY OF CONGRESS}

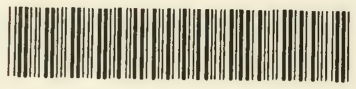
00025864505 